\title{
COBBOOM: The Continental Breakup and Birth of Oceans Mission
}

\section{Introduction}

The rupture of continents and creation of new oceans is a fundamental yet primitively understood aspect of the plate tectonic cycle. Building upon past achievements by ocean drilling and geophysical and geologic studies, we propose "The Continental Breakup and Birth of Oceans Mission (COBBOOM)" as the next major phase of discovery, for which sampling by drilling will be essential.

In September 2006, fifty-one scientists from six continents gathered in Pontresina, Switzerland to discuss current knowledge of continental breakup and sedimentary basin formation and how the Integrated Ocean Drilling Program (IODP) can deepen that knowledge (Coffin et al., 2006). Workshop participants discussed a global array of rifted margins (Fig. 1), formulated the critical problems to be addressed by future drilling and related investigations, and identified key rift systems poised for IODP investigations.

\section{Past Achievements}

Scientific ocean drilling has played an essential role in the exploration of rifted continental margins. The North Atlantic Rifted Margins (NARM) endeavor of the Ocean Drilling Program (ODP) addressed conjugate margin pair rift systems ranging from "magma-dominated" (Norway/British Isles-Greenland margins of the offshore-onshore early Tertiary North Atlantic large igneous province (LIP)) to "magma-starved" (Iberia-Newfoundland margins of Late Triassic to Early Jurassic age, Fig. 2.) Geophysical studies

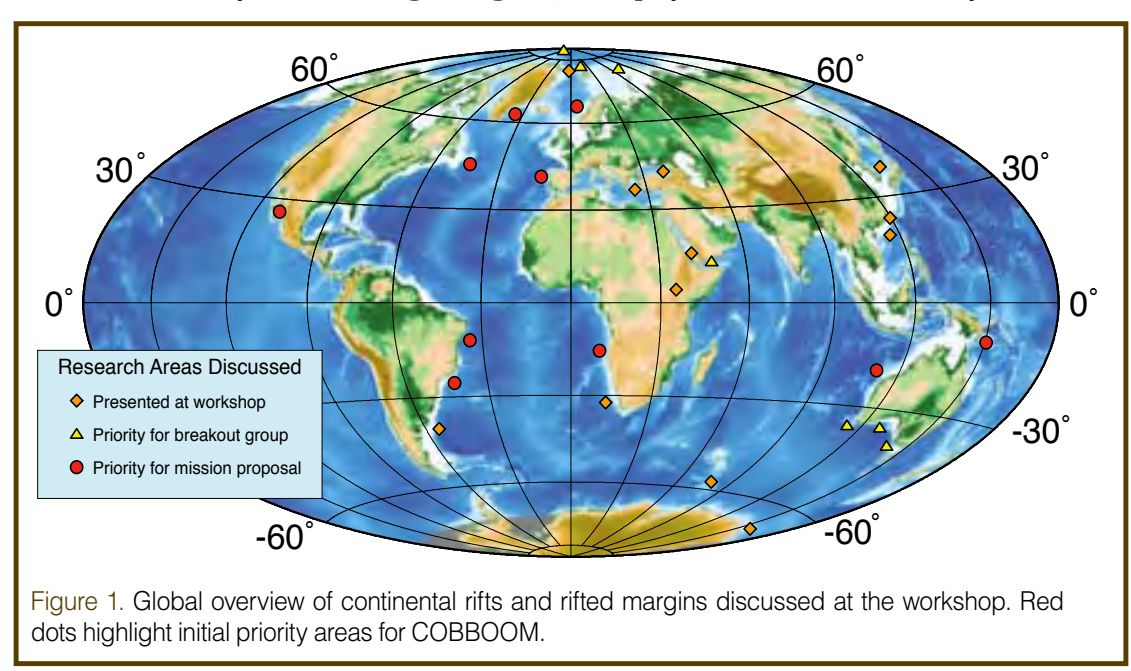

and drilling results from these two conjugate pair rift systems have profoundly changed our view of the processes responsible for such margins.

The drilling of 'seaward dipping reflector' (SDR) wedges of the North Atlantic LIP off the British Isles (Roberts et al., 1984), Norway (Eldholm et al., 1987, 1989) and SE Greenland (Duncan et al., 1996; Larsen et al., 1994, 1999) confirmed them to be a thick series of subaerial lava flows covering large areas. Lavas on the landward side of the SDRs show geochemical evidence of contamination by continental crust, implying that they rose through continental crust during early rifting, whereas oceanward SDR lavas appear to have formed at a seafloor spreading center resembling Iceland. Drilling results from these margins document extreme magmatic productivity over a distance of at least $2000 \mathrm{~km}$ during continental rifting and breakup with temporal and spatial influence of the Iceland plume during rifting, breakup, and early seafloor spreading (Saunders et al., 1998).

Other margins such as Iberia-Newfoundland (Tucholke et al., 2007) appear magma-starved and have been hyperextended by progressive rifting (Lavier and Manatschal, 2006) in stages, with distinct tectonic characteristics controlled by the rheological effects of the gradual thinning of continental crust and uplift of the underlying mantle (Fig. 3). When the crust has been thinned by normal faulting to less than $\sim 10 \mathrm{~km}$, it becomes entirely brittle (Pérez-Gussinyé and Reston, 2001), and tectonism then transitions to spatially focused, closely spaced normal faults that sole into a serpentine detachment at the crust mantle boundary that eventually unroofs upper mantle rocks along a detachment fault exposed at the seafloor. Exhumation of upper mantle rocks continues over a potentially wide region, until mantle uplift generates sufficient magma to initiate seafloor spreading (Tucholke et al., 2007). These results suggest that depth-dependent stretching (DDS) and detachment faulting are major controls on continental rupture and ocean formation.

The ODP also addressed active rifting along a low-angle normal fault in the Woodlark Basin that is propagating into continental lithosphere (Huchon et al., 2002; Taylor et al., 1999a, b). 


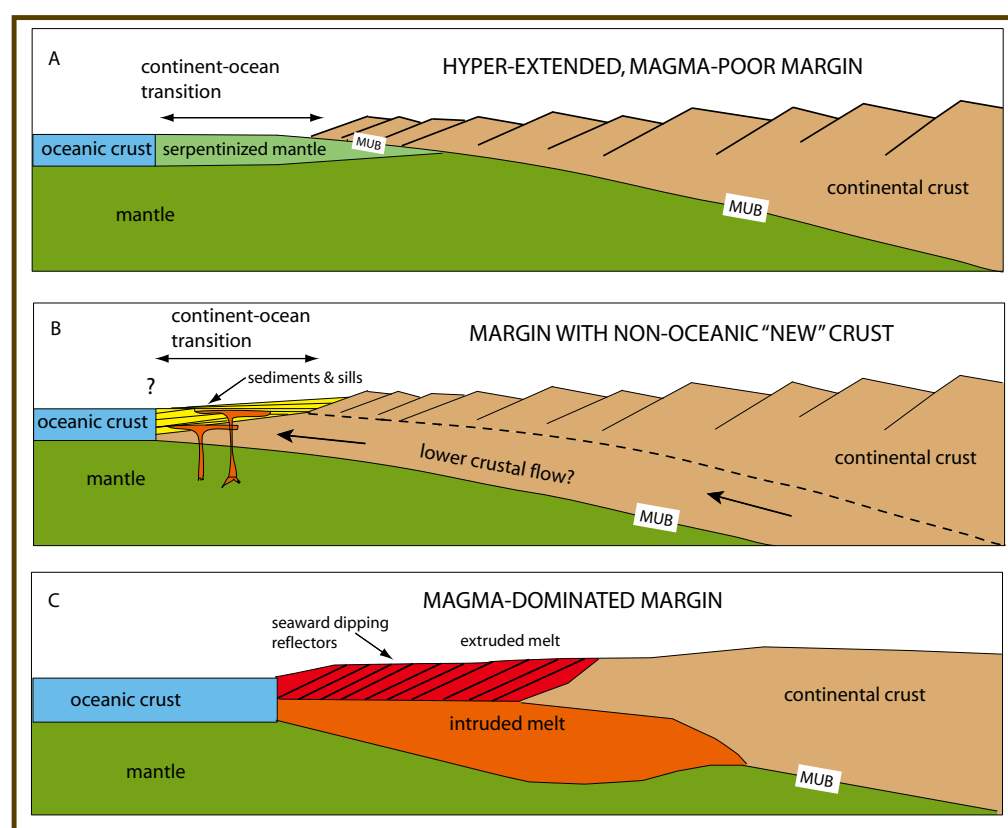

MUB = mafic-ultramafic boundary

Figure 2. Schematic cross sections of $[\mathrm{A}]$ hyper-extended (e.g., Iberia-Newfoundland), [B] non-oceanic 'new' crust (e.g., northern Gulf of California), and [C] magma-dominated (e.g. NW Europe-E Greenland, NW Australia) divergent continental margins.

\section{Scientific Objectives Associated with Continental Rifting}

Variations in the importance and, in particular, the volume of magmatism have led to the classification of margins as "volcanic" or "non-volcanic" (Mutter et al., 1988); however, this binary dichotomy fails to adequately reflect that rifted margins form a spectrum from magma-rich to magma-poor. The key distinction is whether magmatism is more or less than expected from the degree of lithospheric thinning and passive asthenospheric upwelling of normal temperature mantle. Equally important are the timing of magmatism and the strain distribution across margins, i.e., hyper-extended versus a more abrupt transition between continental and oceanic lithosphere. Because a continuum between possible end-members may exist, the focus should be on understanding the fundamental processes causing such variations. Key aspects of continental breakup can only be addressed by drilling and associated studies (Table 1).

More specifically, we need to determine the following at multiple, carefully selected rifted margins: 1) uplift and sub- sidence history; 2) ages and facies of synrift and syn-faulting sediment; 3) timing, volume, chemistry, and style of magmatism; 4) orientation of deformation fabrics, including faults; and 5) ages and facies of postrift sediment. Such information can be used to infer distribution of strain in space and time; deformation mechanics and dynamics; processes within the mantle, including depth and degree of melting, melt migration, and infiltration; and mantle composition, heterogeneity, and dynamics.

We propose drilling programs on well characterized and representative examples, conjugate where possible, of both active and mature rifted margins ranging from magmatic to amagmatic and abrupt to hyperextended. The rift systems described below constitute an initial focus of investigations for COBBOOM.

\section{Gulf of California}

Key Aspects and Problems to be Addressed: The active Gulf of California rift system (Fig. 4) varies along strike in crustal thickness, synrift sediment facies, amount of magmatism, structural style, and width of new seafloor (Lizarralde et al., 2007). The northern basins host an enigmatic type of crust that is $15-20 \mathrm{~km}$ thick, characterized by gravity anomalies and seismic velocities suggestive of silicic as opposed to basaltic material (González-Fernández et al., 2005). Low-angle normal faults are also accessible to both onshore sampling and drilling. In the central basins, magma-sediment interactions and fluid/geochemical fluxes, including methanogenesis, will be studied (Fig. 5). In southern segments, the processes and timing of the synrift to postrift transition (breakup unconformity, basin evolution, margin uplift or subsidence) will be examined.

Regional Setting and Background: The system formed from a major reorganization of the Farallon-North American plate boundary during Neogene time (Lonsdale, 1989). Narrow perched basins adjacent to seafloor spreading centers characterize the southernmost segment, whereas diffuse deformation in an apparent continental setting dominates the northern Gulf (Persaud et al., 2003). In the central Gulf, two segments of the Guaymas basin are narrow and

Table 1. Key aspects of continental breakup.

$\begin{array}{ll}\text { Rift initiation } & \text { Driving forces, rift localization, lithospheric strength, thermal structure. } \\ \begin{array}{l}\text { Tectonics of rifting } \\ \text { Distribution of strain, rheological evolution, mechanisms of crustal thinning, strength of faults, 3-D } \\ \text { rift geometry, mantle exhumation, transition to seafloor spreading. }\end{array} \\ \begin{array}{ll}\text { Melt-rift interactions, mantle heterogeneities, melt production into seafloor spreading stage, } \\ \text { controls on melt production. }\end{array} \\ \begin{array}{l}\text { Initiation of seafloor } \\ \text { spreading }\end{array} & \begin{array}{l}\text { Shen and where, development of seafloor spreading magnetic anomalies, mantle thermal } \\ \text { sedimentary processes and }\end{array} \\ \begin{array}{l}\text { Stratigraphic responses to rifting and breakup, stratigraphy-strain rate relationships, fault pat- } \\ \text { basin evolution }\end{array} & \text { terns and evolution, interactions among erosion, sedimentation, and tectonism. } \\ \begin{array}{l}\text { Environmental } \\ \text { consequences \& impact }\end{array} & \begin{array}{l}\text { Magma interactions with sediment, hydrosphere, and the atmosphere; tectonic and magmatic } \\ \text { controls on ocean gateways. }\end{array}\end{array}$


have slightly thicker crust, suggesting more magmatic input, whereas four segments of the south-central domain are wide, magmapoor rifts (Lizarralde et al., 2007). Simple plate kinematics cannot explain these changes in style because of constant total strain along the rift axis. Rather, along strike variation in pre-existing lithospheric and mantle structure, thermal state, and sediment inputs must have controlled this development.

\section{Proposed Drill Sites:} Several thousand kilometers of multichannel seismic lines (Persaud et al., 2003; Lizarralde et al., 2007; González-Fernández et al., 2005; Aragón-Arreola and Martín-Barajas, 2007) image key structures of the rift basins well suited for addressing the following topics: 1) the possible role of lower crustal flow to fill the gap created by rifting; 2) the role of detachment faults in early rifting and/ or in delaminating continental crust; 3) differences in magmatism in adjacent rift segments along strike; and 4) the relationships between magmatism and global environmental changes (Svensen et al., 2004; Dickens, 2004).

In the northern Gulf (Fig. 4) high heat flow and thick sediment may have caused lower crustal flow and a diffuse rift with enigmatic transitional crust (González-Fernández et al., 2005). It is feasible that sites can sample possible low-angle normal faults and a complete sedimentary section constraining the age of rifting. Igneous intru-
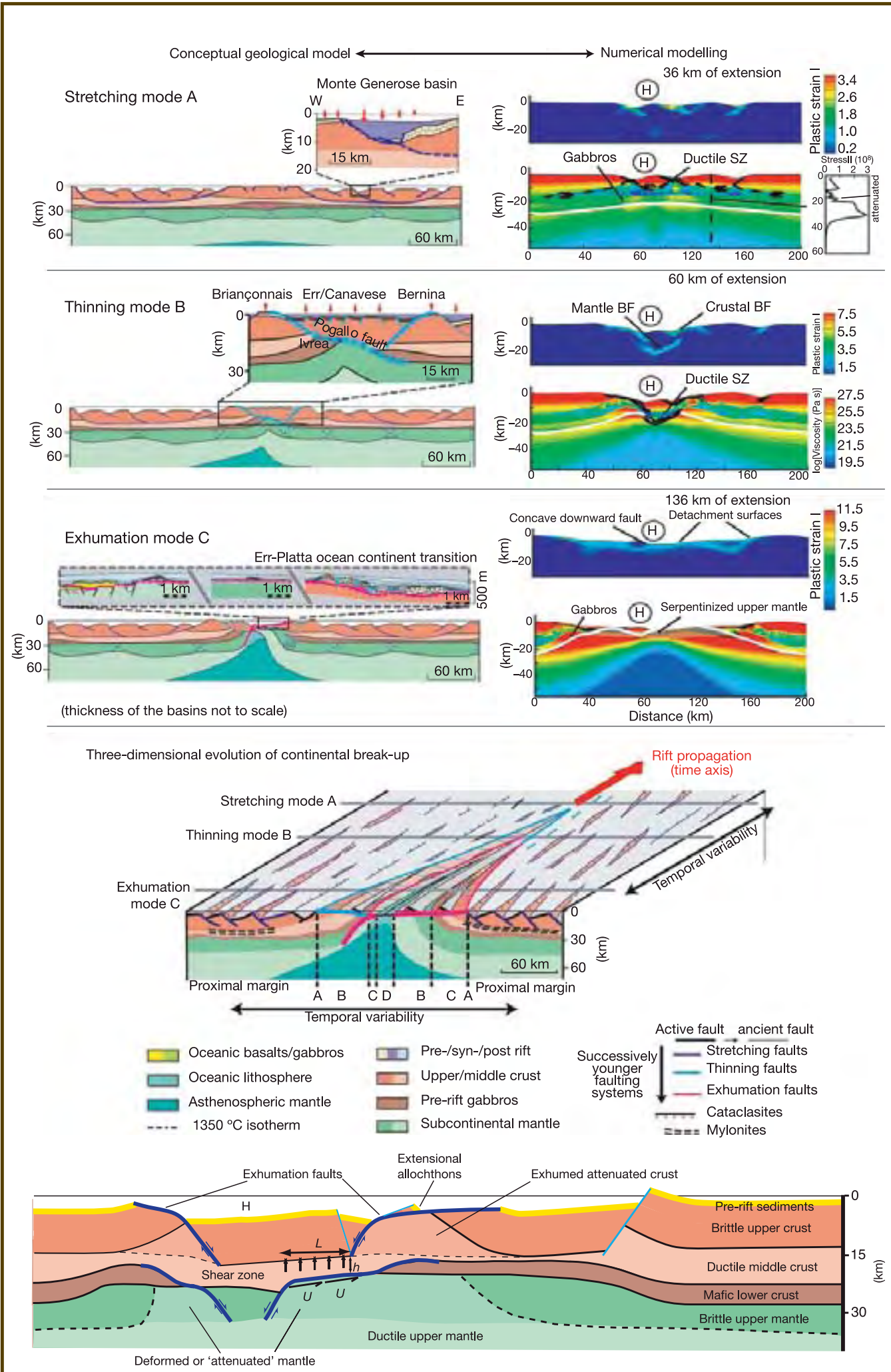

Figure 3. Modeling of the evolution of a continental rift in space and time, not including decompression melting, to better understand the hyper-extended margins of Newfoundland and Iberia (Lavier and Manatschal, 2006). (upper and middle) Conceptual geological and numerical models for different phases of extension that are distinguished by different styles of deformation. The stretching mode $[\mathrm{A}]$ is characterized by listric faulting and differential subsidence of half-grabens. The thinning mode $[\mathrm{B}]$ is the least documented of the modes, but it can be characterized by maximum thinning of the lithosphere and the presence of a major ductile shear zone accommodating differential motion (up to $10 \mathrm{~km}$ upward) between the upper crust and the lower crust/upper mantle. It is accompanied by relatively little uplift of the rift flanks and subsidence in the hanging wall. The exhumation mode [C] is well documented and distinguished by the exhumation of serpentinized upper mantle from $<10 \mathrm{~km}$ depth along a downward-concave fault. Note the similarity between the observed and modeled structures. (lower) Conceptual model for the thinning phase during continental breakup. Note that thinning is accommodated by the simultaneous exhumation of middle crust and upper mantle. 


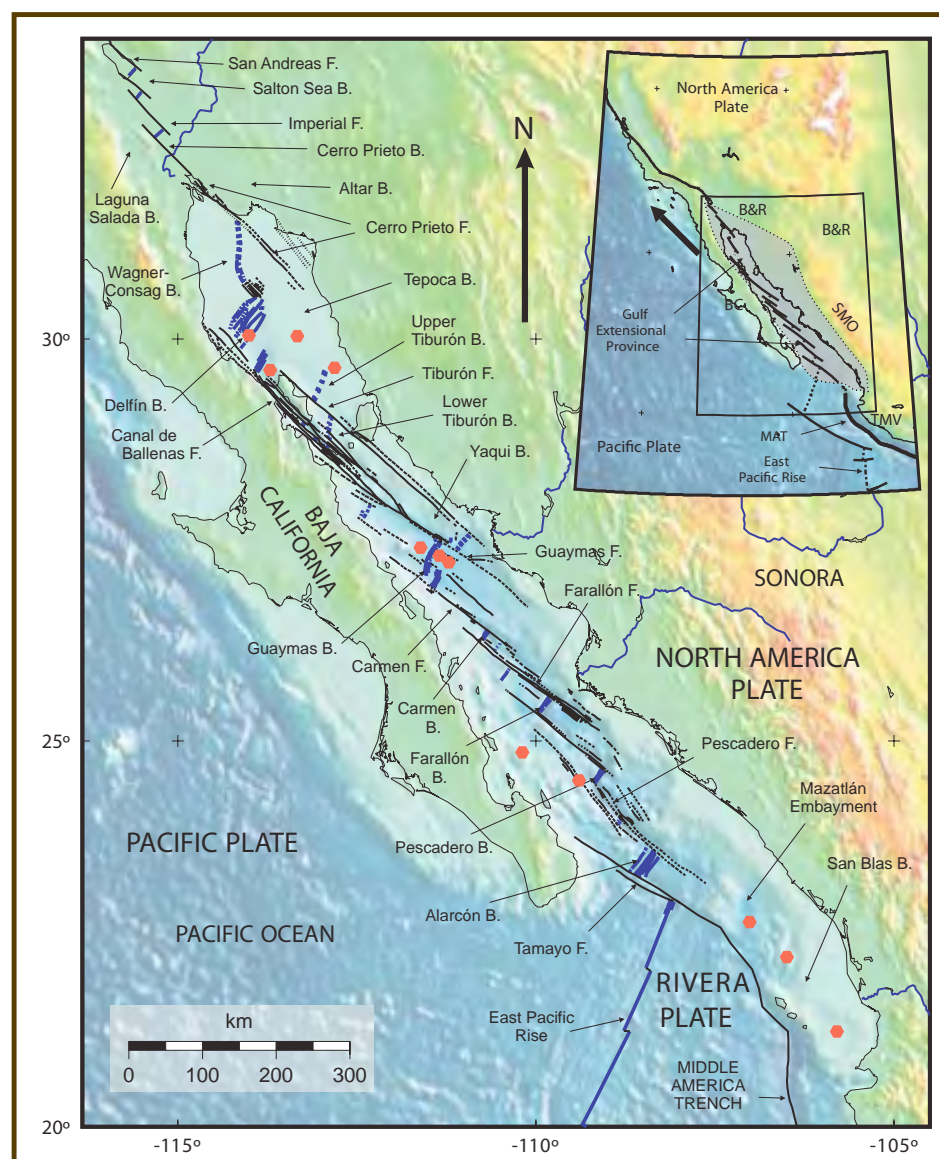

Figure 4. Tectonic map with digital elevations of the Gulf of California region, modified from Aragón-Arreola (2006). This region hosts the modern transtensional boundary between the Pacific and North America plates, comprising spreading centers or extensional basins (blue lines) and faults (black lines). Modern and abandoned basins of the plate boundary are labeled. Red dots show proposed IODP sites. Abbreviations: $F=$ fault, $B=$ basin. Inset: regional map of plate boundary system. Inset abbreviations: $\mathrm{SMO}=$ Sierra Madre Occidental; $\mathrm{B} \& \mathrm{R}=$ Basin and Range Province; BC=Baja California; TMV=Trans-Mexican Volcanic Belt; MAT=Middle America Trench.

sions may constrain interactions among mantle and lower crustal melts and sediment. Ignimbrites erupted during rifting will provide a detailed volcanic history and chronology for the sedimentary section. Sites in the central Guaymas basin (Fig. 4) will address methanogenesis related to igneous intrusion into organic-rich sediment, a potentially important process in the global carbon cycle that is likely to operate in most sedimented rift systems. Sites in the southern Gulf target magma-poor, tectonic extension during rifting, and the transition from rifting to seafloor spreading. Sites along the Alarcon segment, combined with observations from its landward extension (Umhoefer et al., 2007), will address the extension and subsidence history of this segment as it transitioned from magma-poor, tectonic extension to seafloor spreading.

Complementary to drilling, land studies can constrain the age and composition of rift-related volcanism, and provide additional constraints on basin history.

\section{Woodlark Basin}

Key Aspects and Problems to be Addressed: In the Woodlark Basin, westward mid-ocean ridge propagation into continen- tal crust (Fig. 6) allows detailed investigations of continental lithosphere before, during, and after seafloor spreading commences.

Regional Setting and Background: The Woodlark rift is continuous along strike with a seafloor spreading system (Fig. 6). Since Late Miocene time, continental lithosphere of the Papuan Peninsula thickened during Australia-Pacific plate convergence (Davies and Smith, 1971) and has subsequently rifted at some of the highest known rates (Abers, 2001; Wallace et al., 2004). Seafloor spreading initiated after $\sim 200 \mathrm{~km}$ of continental extension in the eastern part of the rift basin prior to $6 \mathrm{Ma}$, and propagated $\sim 800 \mathrm{~km}$ to the modern rift-drift transition adjacent to Moresby Seamount (Taylor et al., 1999a). Adjacent to the westernmost spreading segment is an active, north-dipping low-angle $\left(\sim 30^{\circ}\right)$ normal fault that is currently being dissected by igneous intrusions (Goodliffe and Taylor, 2007). Farther west, seismically active rifts (Ferris et al., 2006) continue toward the active metamorphic core complexes of the D'Entrecasteaux Islands, where exposures of high and ultra-high pressure metamorphic rocks suggest exhumation rates of $\sim 10 \mathrm{~km} \mathrm{Myr}^{-1}$ (Baldwin et al., 2004; Monteleone et al., 2007). The upper plates, separated from the lower plates by shear zones and detachment faults (Hill et al., 1992; Little et al., 2007), consist largely of undeformed mafic and ultramafic rocks. Mylonitic lineations and corrugation surfaces parallel Plio-Pleistocene plate motion vectors (Little et al., 2007).

Proposed Drill Sites: Drilling will address two fundamental issues related to the rift-drift transition in easternmost Papua New Guinea.

1) Rift-drift transition processes. A drilling transect across a nascent spreading segment will address a) the origin of the first magmas at a new spreading center; b) the relationship between magma supply rate and the development of magnetic anomalies associated with seafloor spreading; c) magma-sediment interactions; d) the state of stress at the rift-drift transition; and e) how plate motion accommodation transitions from a low-angle fault to crustal accretion. Drilling will sample the center of the spreading segment and intruded synrift sediment directly to the north and west.

2) Fault patterns and mechanisms responsible for exhuming high and ultrahigh pressure metamorphic rocks from mantle depths ahead of the westward propagating seafloor spreading rift tip, and nature of the rocks above the detachment faults associated with the active D'Entrecasteaux Islands core complexes. Two drilling transects will penetrate sediment and upper plate rocks above the detachment faults, one north of the Prevost Range core complex on Normanby Island ( $<30 \mathrm{~km}$ from the active seafloor spreading tip), and the other north of the Mailolo core complex on northwest Fergusson Island. The active submarine sections of these 


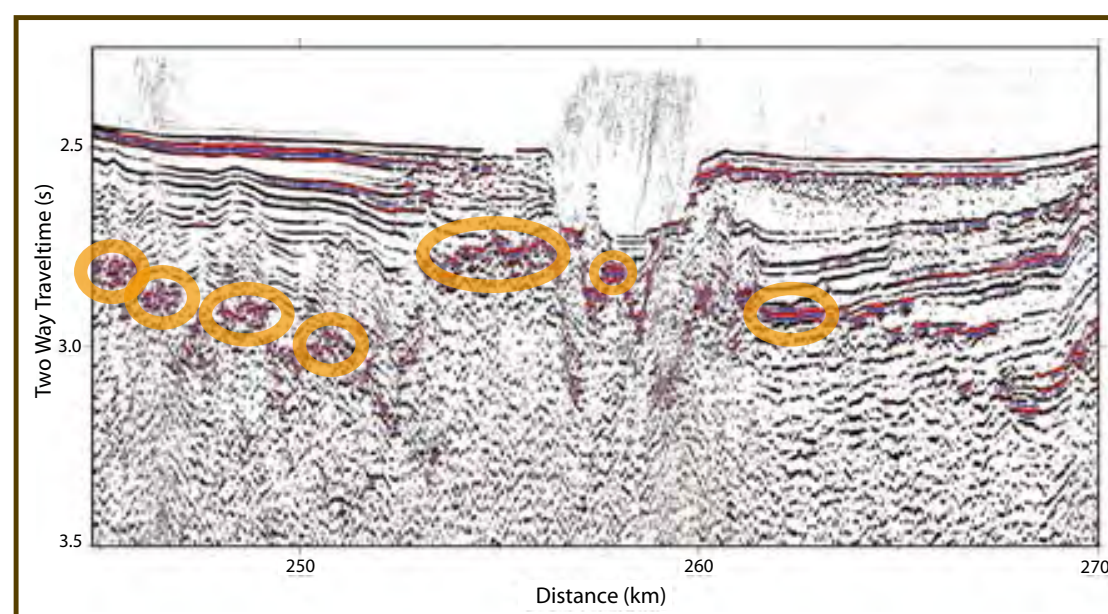

Figure 5. Multichannel seismic profile across the rift graben of the northern Guaymas rift segment of the Gulf of California (see Fig. 4 for location). Sills (circled; identified by reflectivity changes in the sediments they are intruding) drive hydrothermal circulation within the rift valley. Drilling in this vicinity will target thermal and geochemical fluxes as well as geobiological processes including methanogenesis. After Lizarralde et al. (2007).

faults extend below marine sediment that was deposited before and during motion of the hanging wall fault blocks. Drilling will constrain the timing and amount of exhumation directly west of the active seafloor spreading rift and test various models for core complex formation (Abers et al., 2002; Martinez et al., 2001) and for exhumation of high and ultrahigh pressure metamorphic rocks.

\section{North Atlantic Magma-Dominated Margins}

Key Aspects and Problems to be Addressed: The conjugate northwest Europe and east Greenland margins (Fig. 7) are characterized by voluminous magmatism associated with the Iceland plume, and their formation may have had significant environmental impact (Eldholm et al., 1989; Eldholm and Grue, 1994; Larsen and Saunders, 1998; Svensen et al., 2004; Storey et al., 2007). The magmatic productivity cannot be explained by simple decompression melting of normal temperature, sub-lithospheric mantle. Three primary competing hypotheses for excessive magmatism are 1) mantle plume with elevated temperatures (White and McKenzie, 1989); 2) small-scale convection at the base of the lithosphere (Mutter et al., 1988; King and Anderson, 1995); and 3) heterogeneities in mantle source composition (Korenaga, 2004).

Regional Setting and Background: The northeast Atlantic conjugate rifted margins show evidence for extensive magmatism including SDRs, igneous intrusions, and high seismic velocity bodies at the base of the crust attributed to magmatic underplating (Fig. 7). The conjugate margins are segmented along strike by the northwest-trending Jan Mayen Fracture Zone and the Bivrost Lineament, which separate the Møre, Vøring, and Lofoten margins and their conjugates at the Jan
Mayen microcontinent and off northeastern Greenland (Eldholm et al., 2002). The margin segments are characterized by different tectono-magmatic styles and sediment distributions, with magmatism decreasing from the Vøring segment to the north and south.

Proposed Drill Sites: The overall plan is for two shallow basement penetration transects (eleven holes) located north and south of the Jan Mayen Fracture Zone (Fig. 7), respectively, and one deep sub-basalt hole within the southern transect (Fig. 7). A dip transect (six holes; Fig. 7) to examine temporal variability of magmatism extends across the conjugate margin segment pair of central Møre/Jan Mayen Ridge. Each hole is well characterized by high quality seismic reflection data. A strike transect to sample breakup-related volcanic rocks in different margin segments as well as facies units extends along the Norwegian margin. The main segments to be drilled include 1) the central Møre margin (i.e., the location of the dip transect); 2) the southern Vøring margin (transform margin related volcanism); 3) the northern Vøring margin (voluminous volcanic complex); and 4) the southern Lofoten margin (small volcanic complexes). The deep hole-to examine temporal variability of magmatism and the nature, environment, and implications of the rift and early breakup magmatism-will be a reoccupation of a landward site on the Møre-Jan Mayen Ridge conjugate margin transect. Specific issues to be addressed by drilling are 1) melt sources and melting conditions, 2) timing of magmatism, 3) spatial and temporal variations of volcanism, 4) eruption environment and vertical movements, 5) along-axis variations in melt production, and 6) consequences of excessive magmatism for environmental change.

Overall, geophysical (including two-dimensional, threedimensional, and wide-angle seismic) and geological (including DSDP, ODP, and commercial drilling) data sets for the North Atlantic LIP are comprehensive and of high quality.

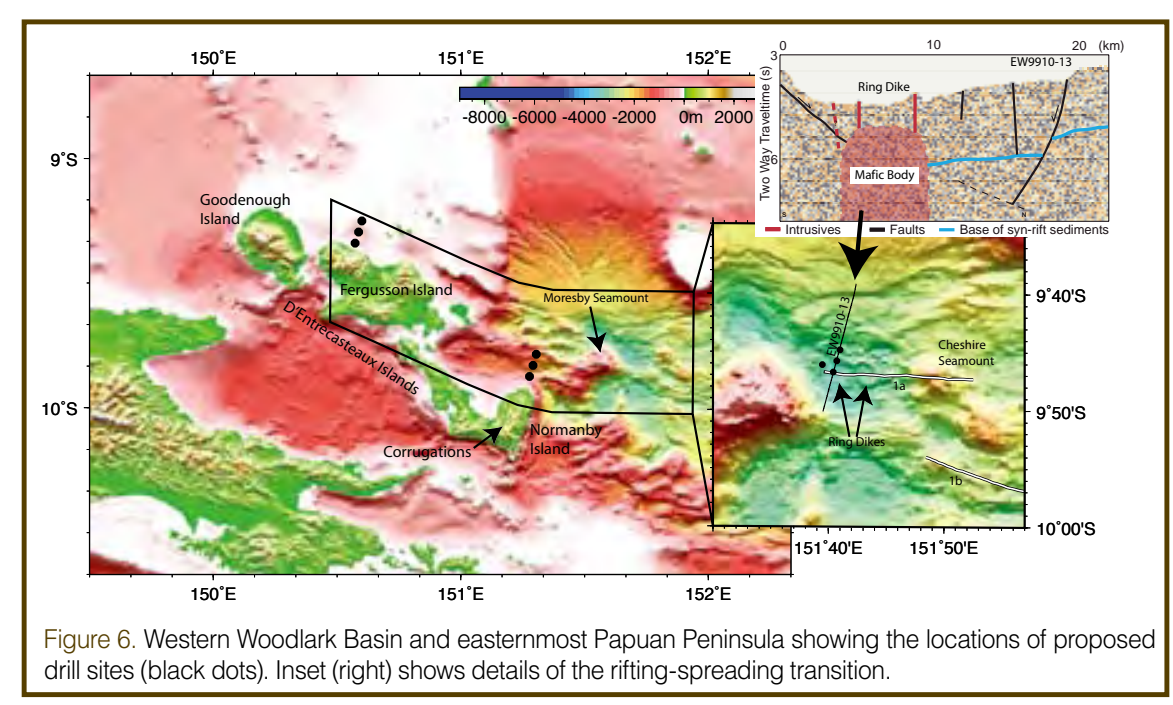




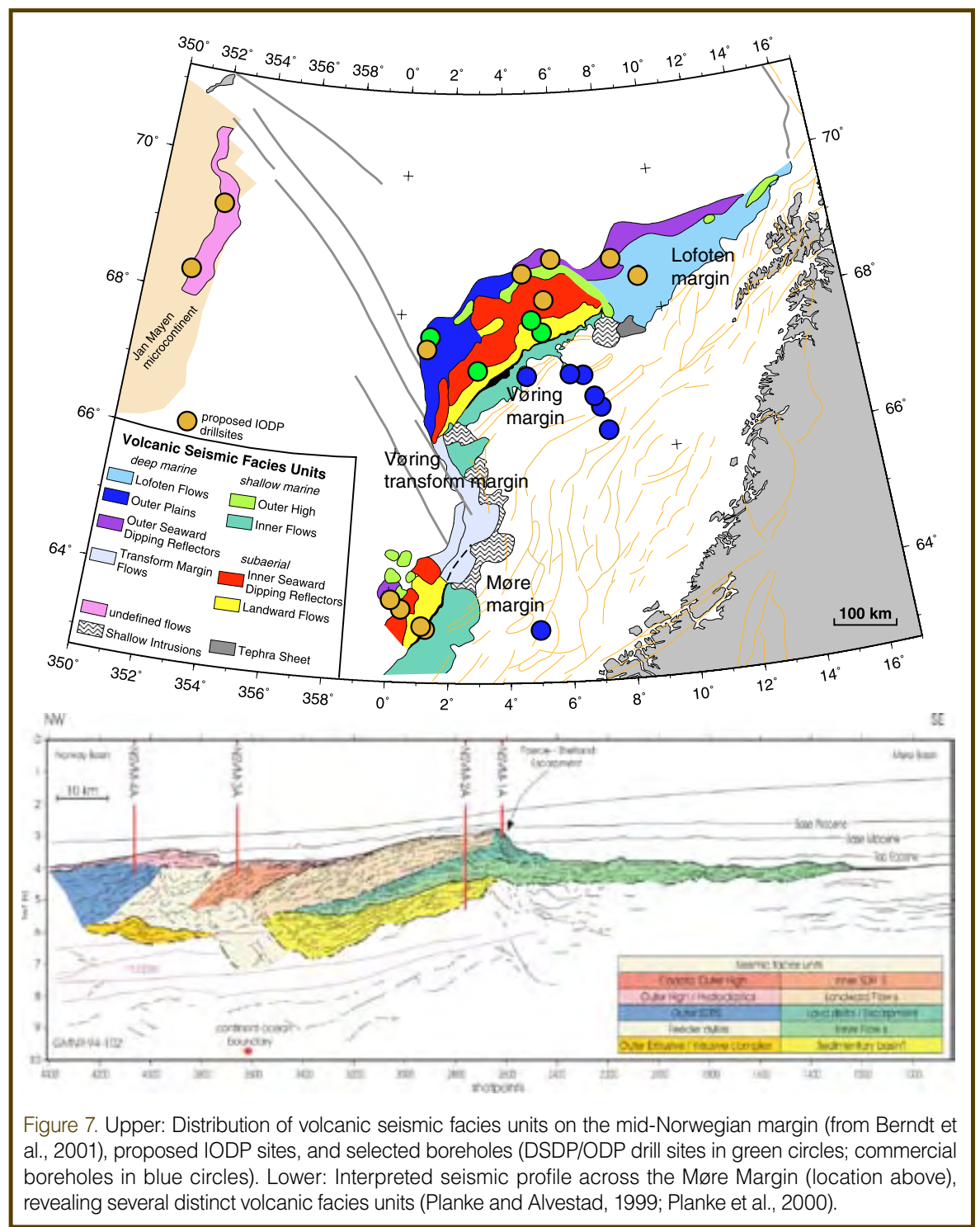

identified (Srivastava et al., 2000; Russell and Whitmarsh, 2003), whereas in the north, M0 (124.5-125 Ma) appears to be the oldest anomaly. However, some evidence indicates that pre-spreading rifting continued into late Aptian time ( 112 Ma; Boillot et al., 1987; Reston, 2005), supporting the idea that the earliest 'seafloor spreading' magnetic anomalies may have originated from unroofed manthe rather than igneous crust formed at a focused spreading center.

Such uncertainties in timing of key events preclude a thorough understanding of dynamic processes because neither rates nor spreading mechanisms are yet accurately known. Another outstanding problem is how the crust was thinned to only a few kilometers, challenging many tenets of lithospheric rheology and isostasy. Some combination of polyphase faulting and DDS seems likely, but the relative importance of the two is controversial (Davis and Kusznir, 2004; Reston, 2007). Similar problems characterize other rifted margins-the South Atlantic (Moulin et al., 2005), Northwest Australian (Driscoll and Karner, 1998), the Labrador Sea (Chian et al., 1995), and the Parentis basin (Pinet et al., 1987).

Proposed Drill Sites: A key objective is to determine the timing of events, which

\section{Newfoundland-lberia Rift}

Key Aspects and Problems to be Addressed: The Iberia and Newfoundland margins (Fig. 8) lack extensive magmatism; they are hyper-extended, characterized by polyphase and diachronous rifting, detachment faulting, and mantle serpentinization and unroofing (Pérez-Gussinyé and Reston, 2001; Reston, 2005; Tucholke et al., 2007). Thin sedimentary cover makes tectonic targets uniquely accessible to drilling. Key problems concern the timing of rifting (along and across the margins), breakup, and the onset of seafloor spreading; the mechanism(s) of extreme crustal thinning; the role of detachment faulting in mantle unroofing; and the nature of basement within the continent-ocean transition.

Regional Setting and Background: During Late Jurassic and Early Cretaceous periods, rifting localized between Newfoundland and Iberia, and the two separated. Breakup propagated from the Central Atlantic northward (Srivastava et al., 2000), but critical details remain controversial. In the south of the Newfoundland-Iberia region, seafloor spreading anomaly M3 (128-130 Ma; Gradstein et al., 2004) has been is needed for a quantitative understanding of the rates of processes associated with final thinning, crustal separation, lower crust and mantle exhumation, the onset of mantle melting, and seafloor spreading. Complete sedimentary sections on both margins are required to achieve this objective (Fig. 8). Well defined synrift wedges above a probable detachment (S) on the Iberia (Galicia Bank) margin and relatively thin sedimentary cover on the conjugate Newfoundland (Flemish Cap) margin provide unique opportunities to establish the timing of events. Another major objective is to test competing ideas on how lithosphere deforms during the final thinning phase of extension leading to exhumation of lower crust and mantle. Thinned continental crust must be sampled at key locations to achieve this objective (Fig. 8).

Flemish Cap. Drilling will help determine 1) the role of hypothesized concave-down faults in exhumation of lower crust and upper mantle during late breakup; 2) the interplay among tectonic, magmatic, and serpentinization processes in hyper-extended rift environments; 3) whether continental crust was removed completely amagmatically; 4) if initial melt products were distributed asymmetrically, with more 
melt on the Newfoundland side; 5) when and how rifting transitioned to seafloor spreading; 6) controls on the localization of deformation into serpentinized shear zones; and 7) when asymmetries between Galicia Bank and Flemish Cap developed. The most landward sites lie on the continental slope where continental crust is $<5 \mathrm{~km}$ thick, and will provide key information on rock types where extreme thinning with little to no upper crustal extension is observed in seismic sections. The sites will sample as much stratigraphy as possible to constrain timing as well as penetrate into basement rocks. The most seaward sites will test competing hypotheses for the formation of transition zone crust, mantle exhumation, and formation of anomalously thin oceanic crust.

Galicia Bank. Drilling will recover complete sedimentary sections at two sites that will help establish the timing and geometry of fault block movements associated with the formation of the 'S' reflection and emplacement of the peridotite ridge just prior to seafloor spreading (Fig. 8). One site (GBB-7A) will penetrate the 'S' reflection, hypothesized to represent a regional detachment surface. Data from overlying strata will constrain the timing of any motion along the surface and dip angles during motion. Coring the hypothesized detachment will
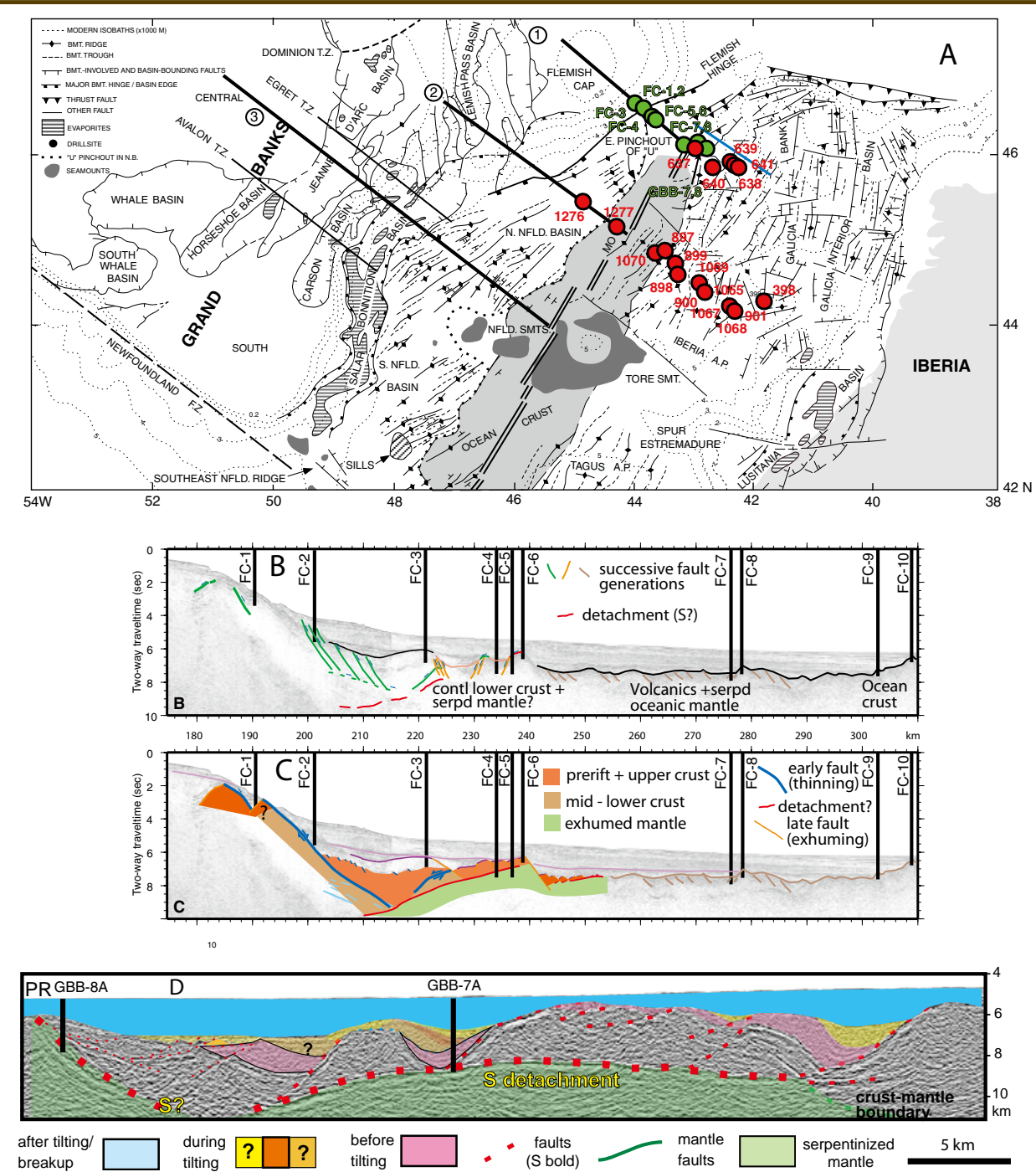

Figure 8. Summary of proposed drilling on the conjugate Newfoundland-lberia hyper-extended margins. [A] Reconstruction of Iberia to Newfoundland at magnetic anomaly M0 time (124.5-125 Ma) (Srivastava et al., 2000). Red numbered dots are drill sites from ODP Legs 103, 149, 173, and 210. Green lettered dots are proposed drill sites in proposal 692 (FC-X) and proposal 657 (GBB-X). FC-8A to FC-10A are on crust younger than M0 and therefore are not shown. Thick lines labeled 1, 2, and 3 are the main SCREECH (Study of Continental Rifting and Extension of the Eastern Canadian shelf) transects along which both seismic reflection and refraction data were collected. Location of profile in part [D] is shown in blue. Figure adapted from Tucholke et al (2004). [B], [C]. Alternative interpretations of SCREECH 1 (Hopper, pers. comm.) showing location of drill sites which will test these and other models of breakup. [D] Depth image of Galicia margin (Reston et al., 2007) showing hypothesized detachment fault S beneath blockbounding faults. Drilling here will constrain nature and mechanics of $\mathrm{S}$, age of overlying synrift wedges and evolution of mantle peridotites.

reveal deformation above and

below the fault while it was active. Another site (GBB-8A) will penetrate a basin and the eastern flank of the peridotite ridge. While the top of the ridge has been sampled, little is known about its internal structure and mode of formation, and when the ridge was exposed at the seafloor.

\section{South Atlantic Margins}

Key Aspects and Problems to be Addressed: Large data sets from the conjugate margins of the South Atlantic suggest that the crust here has been thinned more than can be explained by the observed faults. Drilling of well imaged synrift and early postrift sediment infill of marginal sag basins will provide critical information on timing and facies for understanding margin evolution, including the cause of the extension discrepancy.

Regional Setting and Background: Rupture between South America and Africa propagated from south to north in the Late Jurassic and Early Cretaceous time as the South Atlantic Ocean formed. The resulting South Atlantic passive margins can be divided broadly into three provinces. The first province, the South of Walvis, voluminous magmatism led to 100-km-wide SDRs within the crust along both the Argentine and Namibian conjugate margins. The second province, the North of Walvis Ridge-the rifted margin of eastern Brazil and its conjugate Angola, Congo, and Gabon margins (Fig. 9) —also experienced volcanism during breakup, but 


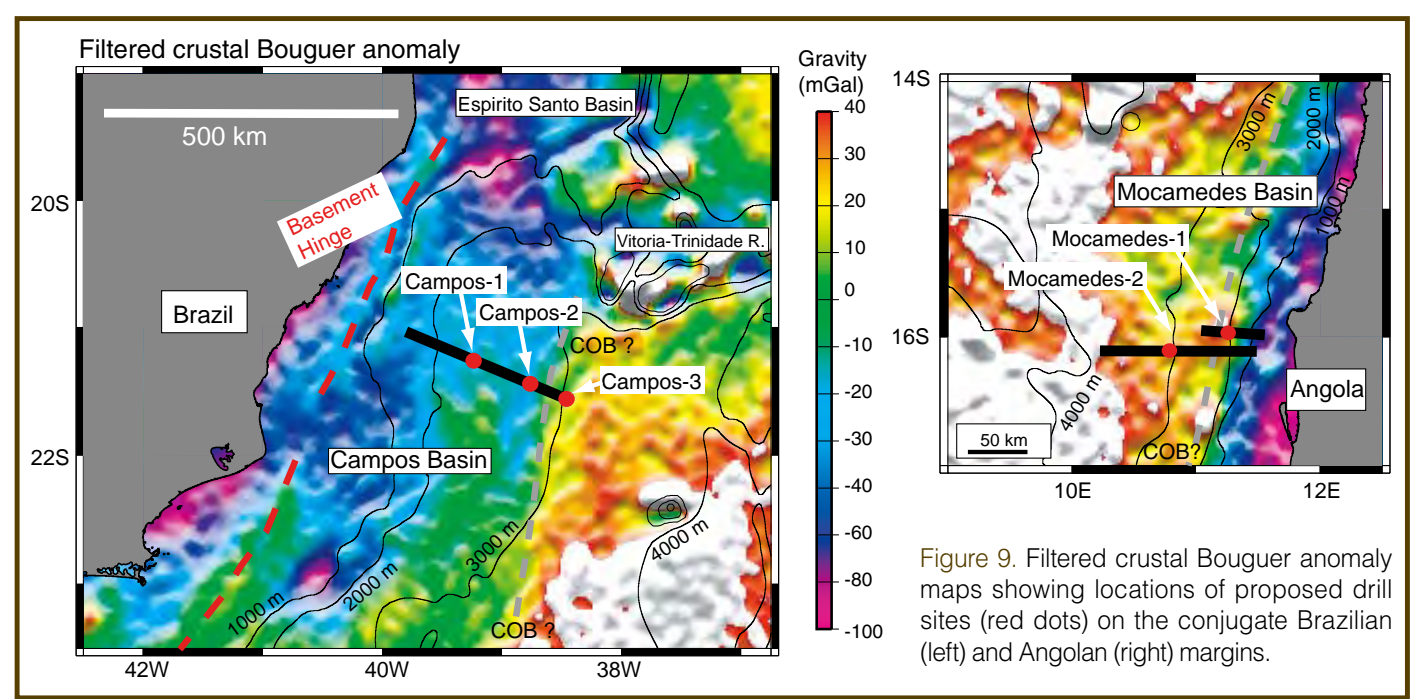

not sufficiently voluminous to form SDRs. Synrift and postrift sedimentation was dominated by Aptian salt, carbonate platforms, and clastic sediment. The third province, the conjugate rifted margins of the equatorial Atlantic, are narrow compared to the hyper-extended margins to the south. Synextensional sag basins, where salt was deposited and mobilized, are found in both the Campos Basin offshore Brazil and the Kwanza Basin offshore Angola. The relative timing of Early Cretaceous synrift volcanism, evaporite deposition, and onset of seafloor spreading are controversial. The seaward edge of the Aptian salt basin may lie on thick SDR wedges (Jackson et al., 2000), implying that salt was deposited after final continental breakup; volcanic edifices in the continent-ocean transition zone probably acted as barriers between the episodically dry marginal basin and the open ocean where new oceanic crust was forming. However, Aptian salt is also abundant in the vicinity of the Congo Fan, where no thick igneous crust or SDRs are imaged in the continent-ocean transition zone. Even in the absence of a potentially bounding basement high, the seaward limit of autochthonous salt appears to lie close to the inferred landward limit of oceanic crust (Marton et al., 2000). Evaporites may even have been deposited on serpentinized mantle in the continent-ocean transition zone (Moulin et al., 2005). Mantle exhumation prior to continental breakup is well characterized from the Newfoundland-Iberia rift, and conceptual models show how continental mantle may be exhumed by lowangle normal faults (Lavier and Manatschal, 2006). However, whereas mantle was exhumed well below sea level along the Newfoundland rift (Tucholke et al., 2007), the continentocean transition zone of the central South Atlantic appears to have been close to sea level prior to breakup.

Proposed Drill Sites: Drill sites in the Campos Basin offshore Brazil and the Moçamedes Basin offshore Angola will establish the tectonic setting of marginal basin formation in the central South Atlantic (Fig. 9). Two sites in the Campos Basin lie at the seaward end of a sag basin; drilling will establish the timing and environment of Aptian salt basin formation. A third site on the Brazilian margin, just seaward of the continent-ocean transition, will sample the oldest oceanic crust. In the Moçamedes Basin on the conjugate Angolan margin, basement will be penetrated where a lowangle fault appears to have ex-humed continental mantle. In total, combined site survey characterization and drilling of the sites will investigate 1) the applicability of conceptual models developed from Newfoundland-Iberia rift characteristics to South Atlantic margins; 2) the age of the first oceanic crust, and relative timing of both continental breakup and the deposition of pre-salt sag sequences; 3) the nature and composition of the crust on which pre-salt sequences were deposited; 4) interpreted exhumed continental mantle in the continent-ocean transition zone; 5) the possible existence of top-basement detachment faults; and 6) synrift and early postrift subsidence along a geophysical transect of the conjugate margins.

\section{NW Australian Magma-Dominated Margin}

Key Aspects and Problems to be Addressed: The northwest Australian magma-dominated (rifted) margin (Fig. 10) is segmented, and igneous rock volumes vary considerably along strike, without clear evidence for a related mantle plume (Mutter et al., 1988; Hopper et al., 1992; Symonds et al., 1998; Planke et al., 2000). This makes the margin a strong candidate to test the edge-driven/small-scale convection hypothesis for generating excessive magmatism. Temporal and along-strike variations in melt production and temporal and spatial relationship(s) between rifting and magmatism are secondary objectives.

Regional Setting and Background: The western Australian margin can be divided into four main segments separated by major fracture zones: Argo, Gascoyne, Cuvier, and Perth (Fig. 10). The entire margin exhibits breakup magmatism in the form of sills, SDRs, hyaloclastic buildups, and magmatic underplating that formed during Callovian ( 163 Ma) Argo margin breakup and subsequent Valanginian ( 138 Ma) Gascoyne, Cuvier, and Perth margin breakup (Planke et al., 2000; Symonds et al., 1998). The conjugate margins have been subducted or obducted. Two main hypotheses-mantle plume (White and McKenzie, 1989) and edge-driven/smallscale convection (Mutter et al., 1988; King and Anderson, 1998; Korenaga, 2004) — have been proposed for the formation of these massive igneous constructions (Coffin et al., 2002; Ingle et al., 2002; Müller et al., 2002). Because it cannot be convincingly tied to a well established hotspot track, the 
western Australian margin is a highly promising candidate for testing alternative hypotheses for magmatic margin formation (Planke et al., 2000).

If a plume was involved in the formation of the western Australian margin, then the Wallaby Plateau-Zenith Seamount province probably represents the post-breakup track of the plume. This province extends some 1200 $\mathrm{km}$ from the continent, across a continentocean transition zone likely associated with composite continental and magmatic plateaus, and into a normal ocean basin, providing an ideal opportunity to examine variations in continental contamination in time and space. Documenting the presence or absence of a geochemical plume signature within igneous basement of the Cuvier margin will therefore be a critical complement to previous and ongoing studies of the North Atlantic igneous province.

Proposed Drill Sites: The objectives are as follows: 1) to distinguish between an edge- vs. plume-driven cause for magmatism along a rifted margin; 2) to examine rift and breakup duration, and subsidence history; 3 ) to investigate the formation and crustal nature of marginal plateaus; 4) to understand the temporal development of multiple SDR wedges; and 5) to determine age, volume, duration, and environment of volcanism. To address these objectives,

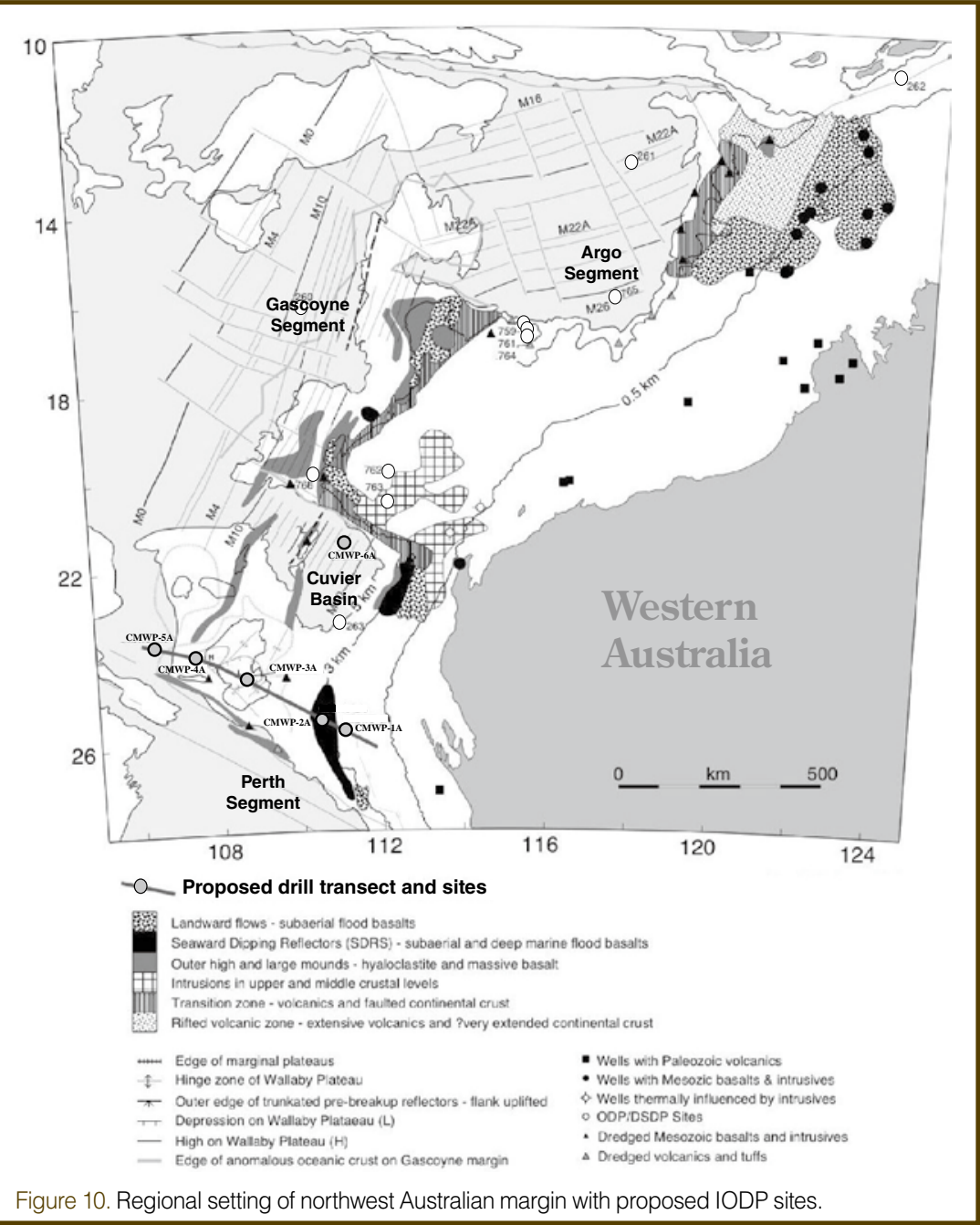

a five-hole transect across the southern Cuvier margin and the Wallaby Plateau as well as a reference hole in similar age oceanic crust of the nearby Cuvier Abyssal Plain are envisioned (Figs. 10 and 11). The holes will sample i) multiple SDRs across the margin; ii) the Wallaby Plateau, and iii) oceanic crust. The petrology and geochemistry of the recovered rocks will be used to determine melting conditions, magma reservoir type (asthenosphere, lithosphere, plume), and contamination by continental lithosphere. Precision age determinations will constrain the temporal and spatial evolution of the magma source. Regionally, the west Australian margin is relatively well investigated by seismic surveys, dredging, and commercial drilling on the continental shelf.

\section{Essential Complements to Drilling}

We now recognize that 2-D seismic technology does not meet the challenge of contemporary research in rifting and breakup, which are fundamentally 3-D processes. As part of its strategy in investigating rifting and breakup, the IODP should integrate acquisition and interpretation of 3-D seismic reflection data with overall program planning.

Land-based geological research has been a valuable complement to ocean drilling and marine geophysics at several rifted margin systems. The Gulf of California is a good example of a rift system that is only partly submerged. Similar opportunities are offered by the Woodlark Basin, where metamorphic core complexes and other rifting components are exposed on islands, and in the North Atlantic LIP, where flood basalts and related rocks crop out in the British Isles

To date, seismic studies of rifted continental margins by the academic community have been almost entirely 2-D, comprising widely spaced profiles relative to the lateral scale of faults and stratigraphic variations.

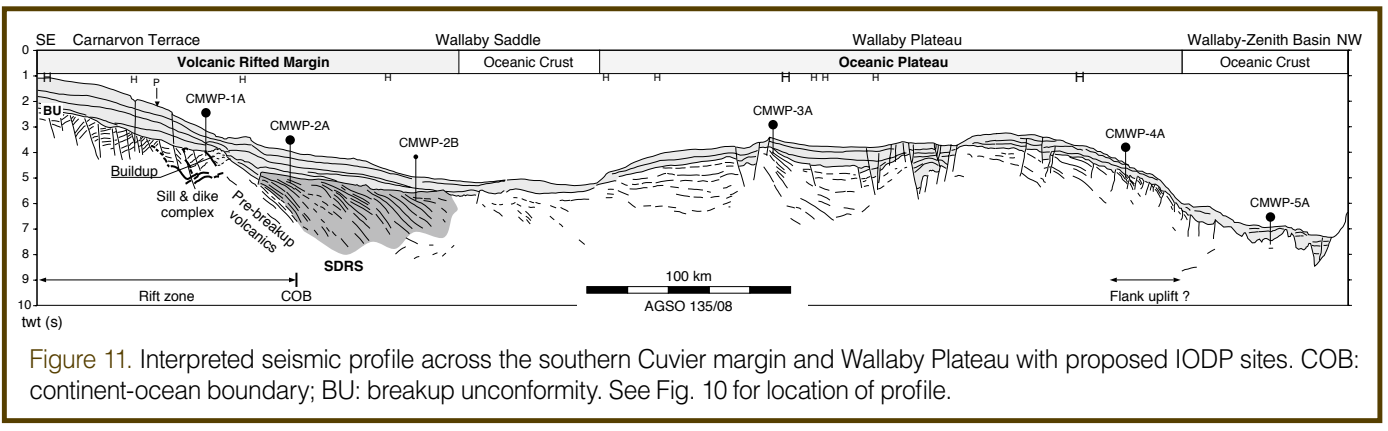




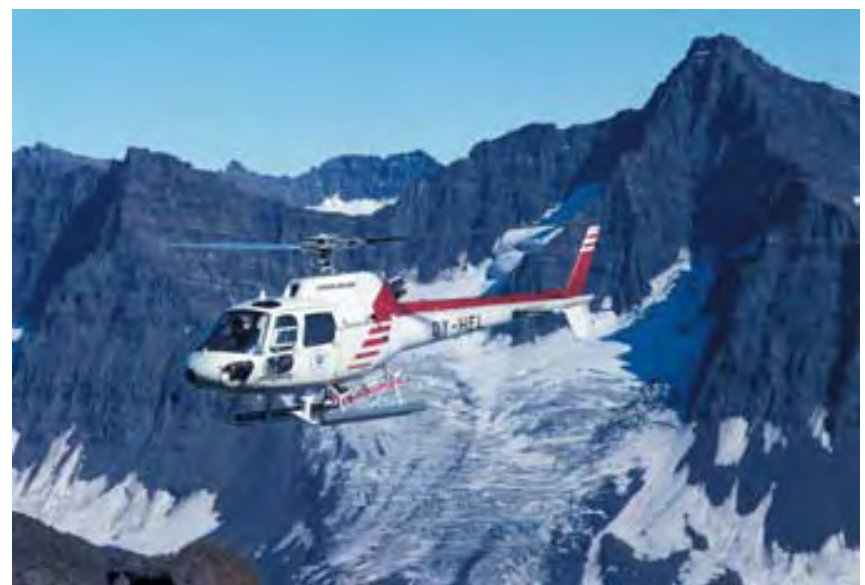

Figure 12. Early Tertiary flood basalt sequence in eastern Greenland associated with rifting and breakup between eastern Greenland and northwestern Europe, highlighting opportunities along some margins for synergetic onshore-offshore studies.

and Greenland (Fig. 12). The study of rift systems now exposed on land in mountain belts is another way that the advantages of field geology can contribute to the study of rift systems, as exemplified by comparisons between the Alpine Tethys rift system exposed in the Alps (Fig. 13) and the Iberia/Newfoundland rift system (Manatschal, 2004; Lavier and Manatschal, 2006).

Modeling the processes of continental rifting is increasingly important for making predictions that can be tested by drilling. Forward dynamic models now provide insights into magmatism accompanying breakup (Boutilier and Keen, 1999; Nielsen and Hopper, 2004) as well as primary controls on passive margin width, symmetries/asymmetries, and evolution from wide, diffuse rifting into narrow, localized rifting resulting in the formation of passive margins (Huismans and Beaumont, 2003, 2007; Lavier and Manatschal, 2006).

The study of continental breakup and sedimentary basin formation offers opportunities for significant collaboration between the hydrocarbon industry and the IODP. During the

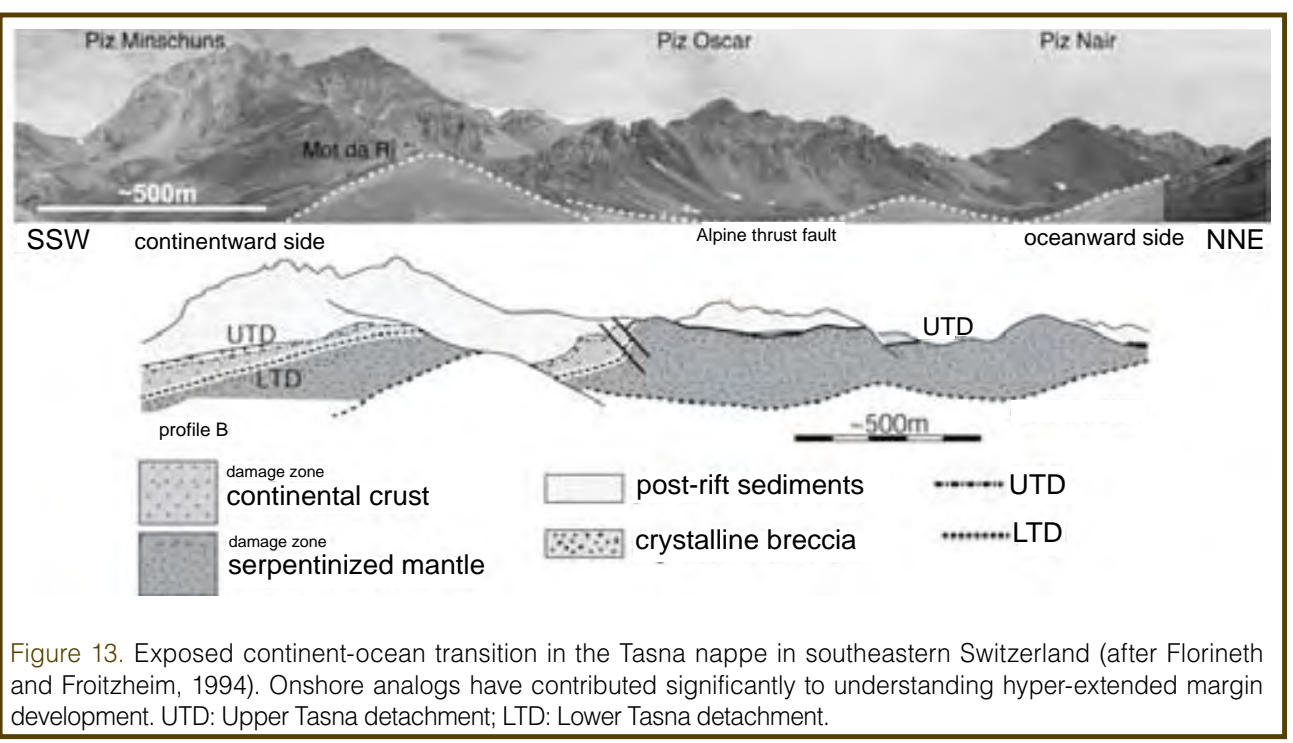

workshop, interest in collaboration was highest for the conjugate rifted margins of the South Atlantic.

\section{Technical Requirements}

COBBOOM will require a combination of existing IODP technology and the development of new technology. Proposed deep and challenging drilling will require the use of both riser and non-riser drills. Where water depths are less than $2500 \mathrm{~m}$, we anticipate using riser capability, casing, and mud circulation to increase hole stability and improve the likelihood of deep penetration. However, some holes have the goal of sampling highly stretched continental crust and upper mantle beneath relatively thin sediment cover and in much deeper water. For such holes, ultra-long drill strings deployed in a non-riser mode and supported by extensive casing programs will be required.

Improved methods of core orientation in sedimentary and crystalline rocks will improve our ability to relate microstructures and faults in the core to the strain distribution in the rifting system. In active rift environments, borehole observatories will be used to monitor the presence and pressure of fluids in faults active during rifting. Technology currently being developed to monitor microseismicity near the boreholes will assist in understanding its relationship to fluid pressure variations.

\section{Acknowledgements}

The authors appreciate input to this paper by participants in the IODP Workshop on Continental Breakup and Sedimentary Basin Formation as well as contributors who did not attend the workshop. We thank the IODP for providing the principal funding for the workshop held in Pontresina, Switzerland on 15-18 September 2006. We thank InterMARGINS for making it possible for scientists from non-IODP member countries to participate in the workshop. Gianreto Manatschal handled the logistics of the workshop and led an incredible field trip to a rifted margin crust and exhumed upper mantle in the Alps. Finally, we acknowledge the essential contributions of Kelly Kryc of IODP-MI who organized the workshop.

\section{References}

Abers, G.A., 2001. Evidence for seismogenic normal faults at shallow dips in continental rifts. In Wilson, R.C.L., Whitmarsh, R.B., Taylor, B. and Froitzheim, N. (Eds.), Non-volcanic Rifting of Continental Margins: A Comparison of Evidence from Land and Sea, Geological Society of London Special Publication 187, 305-318. 
Abers, G.A., Ferris, A., Craig, M., Davies, H., Lerner Lam, A.L., Mutter, J.C., and Taylor, B., 2002. Mantle compensation of active metamorphic core complexes at Woodlark rift in Papua New Guinea. Nature, 416:862-866, doi:10.1038/ nature 00990

Aragón-Arreola, M., and Martín-Barajas, A., 2007. Westward migration of extension in the northern Gulf of California, Mexico. Geology, 35:571-574, doi:10.1130/G23360A.1.

Baldwin, S.L., Montelone, B.D., Webb, L.E., Fitzgerald, P.G., Grove, M., and Hill, J., 2004. Pliocene eclogite exhumation at plate tectonic rates in eastern Papua New Guinea. Nature, 431:263-267, doi:10.1038/nature02846.

Boillot, G., Winterer, E.L., Meyer, A.W., and Shipboard Scientific Party, 1987. Introduction, objectives, and principal results: Ocean Drilling Program Leg 103, West Galicia Margin. In Boillot, G., Winterer, E.L., et al., Proceedings of the Ocean Drilling Program, Initial Reports 103, College Station, Texas (Ocean Drilling Program), 3-17.

Boutilier, R.R., and Keen, C.E., 1999. Small-scale convection and divergent plate boundaries. J. Geophys. Res., 104:73897403.

Chian, D., Louden, K.E., and Reid, I., 1995. Crustal structure of the Labrador Sea conjugate margin and implications for the formation of nonvolcanic continental margins. J. Geophys. Res., 100:24239-24254, doi:10.1029/95JB02162.

Coffin, M.F., Pringle, M.S., Duncan, R.A., Gladczenko, T.P., Storey, M., Müller, R.D., and Gahagan, L.A., 2002. Kerguelen hotspot magma output since 130 Ma. J. Petrol., 43:1121-1139.

Coffin, M.F., Sawyer, D.S., Reston, T.J., and Stock, J.M., 2006. Continental breakup and sedimentary basin formation. Eos Trans. AGU, 87:528, doi:10.1029/2006EO470006.

Davies, H.L., and Smith, I.E., 1971. Geology of eastern Papua. Geol. Soc. Amer. Bull., 82, 12:3299-3312, doi:10.1130/00167606(1971)82[3299:GOEP]2.0.CO;2.

Davis, M., and Kusznir, N.J., 2004. Depth-dependent lithospheric stretching at rifted continental margins. In Karner, G.D. (Ed.), Proceedings of NSF Rifted Margins Theoretical Institute. New York, N.Y. (Columbia University Press), 92-136.

Dickens, R.G., 2004. Hydrocarbon-driven warming. Nature, 429:513515.

Driscoll, N.W., and Karner, G.D., 1998. Lower crustal extension across the Northern Carnarvon Basin, Australia: evidence for an eastward dipping detachment. J. Geophys. Res.,103:4975-4992, doi:10.1029/97JB03295.

Duncan, R.A., Larsen, H.C., Allan, J.F., et al., 1996. Proceedings of the Ocean Drilling Program, Initial Reports, 163. College Station, Texas (Ocean Drilling Program), 279 pp.

Eldholm, O., and Grue, K., 1994. North Atlantic volcanic margins: dimensions and production rates. J Geophys. Res., 99:29552968, doi:10.1029/93JB02879.

Eldholm, O., Thiede, J., and Taylor, E., 1989. Evolution of the Vøring volcanic margin. In Eldholm, O., Thiede, J., Taylor, E., et al., (Eds.), Proceedings of the Ocean Drilling Program, Scientific Results 104, College Station, Texas (Ocean Drilling Program), 1033-1065.

Eldholm, O., Thiede, J., Taylor, E., et al., 1987. Proceedings of the Ocean Drilling Program, Initial Reports, 104. College Station, Texas (Ocean Drilling Program), 783 pp.

Eldholm, O., Tsikalas, F., and Faleide, J.I., 2002. Continental margin of Norway $62-75^{\circ} \mathrm{N}$ : Paleogene tectono-magmatic segmentation and sedimentation. In Jolley, D.W., and Bell, B.R. (Eds.), North Atlantic Igneous Province: Stratigraphy, Tectonics, Volcanic and Magmatic Processes, Geological Society of London Special Publication 197, 39-68.

Ferris, A., Abers, G.A., Zelt, B., Taylor, B., and Roecker, S., 2006. Crustal structure across the transition from rifting to spreading: the Woodlark rift system of Papua New Guinea. Geophys. J. Intl., 166:622-634, doi:10.1111/j.1365246X.2006.02970.x.

Florineth, D., and Froitzheim, N., 1994. Transition from continental to oceanic basement in the Tasna nappe (Engadine window, Graubunden, Switzerland): evidence for early Cretaceous opening of the Valais Ocean. Schweiz. Mineral. Petrogr. Mitt., 74:437-448.

González-Fernández, A., Dañobeitia, J.J., Delgado-Argote, L.A., Michaud, F., Córdoba, D., and Bartolomé, R., 2005. Mode of extension and rifting history of upper Tiburon and upper Delfin basins, northern Gulf of California: J. Geophys. Res., 110:1-17.

Goodliffe, A.M., and Taylor, B., 2007. The boundary between continental rifting and seafloor spreading in the Woodlark Basin, Papua New Guinea. In Karner, G.D., Manatschal, G., and Pinhiero, L.M. (Eds.), Imaging, Mapping and Modelling Continental Lithosphere Extension and Breakup. Geological Society of London, Special Publication 282, 213-234.

Gradstein, F.M., Ogg, J.G., and Smith, A.G., 2004. A Geologic Time Scale 2004, Victoria, Australia (Cambridge University Press), 589 pp.

Hill, E.J., Baldwin, S.L., and Lister, G.S., 1992. Unroofing of active metamorphic core complexes in the D'Entrecasteaux Islands, Papua New Guinea. Geology, 20:907-910.

Hopper, J.R., Mutter, J.D., Larson, R.L., Mutter, C.Z., and Northwest Australia Study Group, 1992. Magmatism and rift margin evolution: Evidence from northwest Australia. Geology, 20:853-857.

Huchon, P., Taylor, B., and Klaus, A., 2002. Proceedings of the Ocean Drilling Program, Scientific Results, 180, College Station, Texas (Ocean Drilling Program), 47 pp.

Huismans, R.S., and Beaumont, C., 2003. Symmetric and asymmetric lithospheric extension: Relative effects of frictional-plastic and viscous strain softening. J. Geophys. Res., 108(B10), 2496, doi:10.1029/2002JB002026.

Huismans, R.S., and Beaumont, C., 2007. Roles of lithospheric strain softening and heterogeneity in determining the geometry of rifts and continental margins. In Karner, G., Manatschal, G., and Pinheiro, L. (Eds.), Imaging, Mapping, and Modeling Continental Lithospheric Extension and Breakup, Geological Society of London Special Publication 282, 107-134.

Ingle, S., Weis, D., Scoates, J.S., and Frey, F.A., 2002. Relationship between the early Kerguelen plume and continental flood basalts of the paleo-Eastern Gondwanan margins. Earth Planet. Sci. Lett., 197:35-50, doi:10.1016/S0012821X(02)00473-9.

Jackson, M.P.A., Cramez, C., and Fonck, J.-M., 2000. Role of subaerial volcanic rocks and mantle plumes in creation of South Atlantic margins: implications for salt tectonics and source rocks. Mar. Petr. Geol., 17:477-498, doi:10.1016/S02648172(00)00006-4. 
King, S.D., and Anderson, D.L., 1995. An alternative mechanism of flood basalt formation. Earth Planet. Sci. Lett., 136:269279.

King, S.D., and Anderson, D.L., 1998. Edge-driven convection. Earth Planet. Sci. Lett., 160:289-296.

Korenaga, J., 2004. Mantle mixing and continental breakup magmatism. Earth Planet. Sci. Lett., 218:463-473, doi:10.1016/ S0012-821X(03) 00674-5.

Larsen, H.C., and Saunders, A.D., 1998. Tectonism and volcanism at the southeast Greenland rifted margin: a record of plume impact and later continental rupture. In Saunders, A.D., Larsen, H.C., and Wise, S. (Eds.), Proceedings of the Ocean Drilling Program, Scientific Results 152, College Station, Texas (Ocean Drilling Program), 503-534.

Larsen, H.C., Duncan, R.A., Allan, J.F., and Brooks, K., 1999. Proceedings of the Ocean Drilling Program, Scientific Results 163, College Station, Texas (Ocean Drilling Program), 173 pp.

Larsen, H.C., Saunders, A.D., Clift, P.D., et al., 1994. Proceedings of the Ocean Drilling Program, Initial Reports 152, College Station, Texas (Ocean Drilling Program), 977 pp.

Lavier, L.L., and Manatschal, G., 2006. A mechanism to thin the continental lithosphere at magma-poor margins. Nature, 440:324-328, doi:10.1038/nature04608.

Little, T.A., Baldwin, S.L., Fitzgerald, P.G., and Montelone, B., 2007. Continental rifting and metamorphic core complex formation ahead of the Woodlark spreading ridge, D'Entrecasteaux Islands, Papua New Guinea. Tectonics, 26:TC1002, doi:10.1029/2005TC001911.

Lizarralde, D., Axen, G.J., Brown, H.E., Fletcher, J.M., GonzálezFernández, A., Harding, A.J., Holbrook, W.S., Kent, G.M., Paramo, P., Sutherland, F.H., and Umhoefer, P.J., 2007. Variation in styles of rifting in the Gulf of California. Nature, v.448 (7152), P. 466-469, doi:10.1038/nature06035.

Lonsdale, P., 1989. Geology and tectonic history of the Gulf of California. In Winterer, E. L., Hussong, D.M., and Decker, R.W. (Eds.), The Geology of North America Volume N. The Eastern Pacific Ocean and Hawaii. Boulder, Colo. (Geological Society of America), 499-521.

Manatschal, G., 2004. New models for evolution of magma-poor rifted margins based on a review of data and concepts from West Iberia and the Alps. Int. J. Earth Sci., 93:432-466.

Martinez, F., Goodliffe, A.M., and Taylor, B., 2001. Metamorphic core complex formation by density inversion and lower crust extension. Nature, 411:930-934, doi:10.1038/35082042.

Marton, L.G., Tari, G.C., and Lehmann, C.T., 2000. Evolution of the Angolan passive margin, west Africa, with emphasis on post-salt structural styles. In Mohriak, W., and Talwani, M. (Eds.), AGU Geophysical Monograph 115, Washington, DC (American Geophysical Union), 129-149.

Monteleone, B.D., Baldwin, S.L., Webb, L.E., Fitzgerald, P.G., Grove, M., and Schmitt, A.K., 2007. Late Miocene-Pliocene eclogite facies metamorphism, D'Entrecasteaux Island, SE Papua New Guinea. J. Metamorph. Geol., 25:245-265, doi:10.1111/ j.1525-1314.2006.00685.x.

Moulin, M., Aslanian, D., Olivet, J.-L., Contrucci, I., Matias, L., Géli, L., Klingelhoefer, F., Nouzé, H., Réhault, J.-P., and Unternehr, P., 2005. Geological constraints on the evolution of the Angolan margin based on reflection and refraction seismic data (ZaïAngo project). Geophys. J. Intl., 162:793-810, doi:10.1111/j.1365-246X.2005.02668.x.

Müller, R.D., Mihut, D., Heine, C., O'Neill, C., and Russell, I., 2002. Tectonic and volcanic history of the Carnarvon Terrace: constraints from seismic interpretation and geodynamic modelling. In Gorter, J. (Ed.), The Sedimentary Basins of Western Australia 3, Perth, Australia (Petroleum Exploration Society of Australia), 719-740.

Mutter, J.C., 1993. Margins declassified. Nature, 364:393-394, doi:10.1038/364393a0.

Mutter, J.C., Buck, W.R., and Zehnder, C.M., 1988. Convective partial melting: 1. a model for the formation of thick basaltic sequences during the initiation of spreading. J. Geophys. Res., 93:1031-1048.

Nielsen, T.K., and Hopper, J.R., 2004. From rift to drift: mantle melting during continental breakup. Geochem. Geophys. Geosyst., 5:Q07003, doi:10.1029/2003GC000662.

Pérez-Gussinyé, M., and Reston, T.J., 2001. Rheological evolution during extension at passive non-volcanic margins: onset of serpentinization and development of detachments to continental break-up. J. Geophys. Res., 106:3691-3975.

Persaud, P., Stock, J.M., Steckler, M.S., Martín-Barajas, A., Diebold, J.B., González-Fernández, A., and Mountain, G.S., 2003. Active deformation and shallow structure of the Wagner, Consag, and Delfín Basins, northern Gulf of California, Mexico. J. Geophys. Res., 108:2355, doi: 10.1029/2002JB001937.

Pinet, B., Montadert, L., Curnelle, R., Cazes, M., Marillier, F., Rolet, J., Tomassino, A., Galdeano, A., Patriat, P., Brunet, M.F., Olivet, J.L., Schaming, M., Lefort, J.-P., Arrieta, A., and Riaza, C., 1987. Crustal thinning on the Aquitaine shelf, Bay of Biscay, from deep seismic data. Nature, 325:513-516, doi:10.1038/325513a0.

Planke, S., Symonds, P.A., Alvestad, E., and Skogseid, J., 2000. Seismic volcanostratigraphy of large-volume basaltic extrusive complexes on rifted margins. J. Geophys. Res., 105:19335-19351, doi:10.1029/1999JB900005.

Reston, T.J., 2005. Polyphase faulting during development of the west Galicia rifted margin. Earth Planet. Sci. Lett., 237:561-576, doi:10.1016/j.epsl.2005.06.019.

Reston, T.J., 2007. Extension discrepancy at North Atlantic nonvolcanic rifted margins: depth-dependent stretching or unrecognized faulting? Geology, 35:367-370, doi:10.1130/ G23213A.1.

Reston, T.J., Leythaeuser, T., Booth-Rea, G., Sawyer, D., Klaeschen, D., and Long, C., 2007. Movement along a low-angle normal fault: The S reflector west of Spain. Geochem. Geophys. Geosyst., 8:Q06002, doi:10.1029/2006GC001437.

Roberts, D.G., Schnitker, D., et al., 1984. Initial Reports of the Deep Sea Drilling Project, Leg 81, Washington, DC (U.S. Government Printing Office), $923 \mathrm{pp}$.

Russell, S.M., and Whitmarsh, R.B., 2003. Magmatic processes at the west Iberia non-volcanic rifted continental margin: evidence from analyses of magnetic anomalies. Geophys. J. Intl., 154:706-730, doi:10.1046/j.1365-246X.2003.01999.x.

Saunders, A.D., Larsen, H.C., and Wise, S.W., Jr., 1998. Proceedings of the Ocean Drilling Program, Scientific Results 152, College Station, Texas (Ocean Drilling Program), 554 pp.

Srivastava, S.P., Sibuet, J.-C., Cande, S., Roest, W.R., and Reid, I.D., 
2000. Magnetic evidence for slow seafloor spreading during the formation of the Newfoundland and Iberian margins. Earth Planet. Sci. Lett., 182:61-76.

Storey, M., Duncan, R.A., and Swisher, C.C., III, 2007. PaleoceneEocene thermal maximum and the opening of the Northeast Atlantic. Science, 316:587-589, doi:10.1126/science.1135274

Svensen, H., Planke, S., Malthe-Serenssen, A., Jamtveit, B., Myklebust, R., Eidem, T.R., and Rey, S.S., 2004. Release of methane from a volcanic basin as mechanism for initial Eocene global warming. Nature, 429:542-545, doi:10.1038/nature02566.

Symonds, P. A., Planke, S., Frey, Ø., and Skogseid, J., 1998. Volcanic evolution of the Western Australian continental margin and its implications for basin development. In Purcell, P.G.R.R. (Ed.), The Sedimentary Basins of Western Australia 2: Proceedings of the PESA Symposium, Perth, Australia (Petroleum Exploration Society), 33-54.

Taylor, B., Goodliffe, A.M., and Martinez, F., 1999a. How continents break up: insights from Papua New Guinea. J. Geophys. Res., 104:7497-7512.

Taylor, B., Huchon, P., Klaus, A., et al., 1999b. Proceedings of the Ocean Drilling Program, Initial Reports 180, College Station, Texas (Ocean Drilling Program), doi:10.1029/1998JB900115.

Tucholke, B.E., Sawyer, D.S., and Sibuet, J.-C., 2007. Breakup of the Newfoundland-Iberia rift. In Karner, G.D., Manatschal, G., and Pinheiro, L.M. (Eds.), Imaging, Mapping and Modeling Continental Lithosphere Extension and Breakup, Geol. Soc., Spec. Publ., 282:9-46.

Tucholke, B.E., Sibuet, J.-C., Klaus, A., et al., 2004. Proceedings of the Ocean Drilling Program, Initial Reports 210, College Station, Texas (Ocean Drilling Program), 78 pp.

Umhoefer, P.J., Schwennicke, T., Del Margo, M.T., Ruiz-Gerald, G., Ingle, J.C., Jr., and McIntosh, W., 2007. Transtensional faulttermination basins: an important basin type illustrated by the Pliocene San Jose Island basin and related basins in the southern Gulf of California, Mexico. Basin Res., 19:297-322, doi:10.1111/j.1365-2117.2007.00323.x.

Wallace, L.M., Stevens, C., Silver, E.A., McCaffrey, R., Loratung, W., Hasiasta, S., Stanaway, R., Curley, R., Rosa, R., and Taugaloidi, J., 2004. GPS and seismological constraints on active tectonics and arc-continent collision in Papua New Guinea: implications for mechanics of micro-plate rotations in a plate boundary zone. J. Geophys. Res., 109:B05404, doi:10.1029/2003JB002481.

White, R.S., and McKenzie, D.P., 1989. Magmatism at rift zones: the generation of volcanic continental margins and flood basalts. J. Geophys. Res., 94:7685-7729.

\section{Authors}

Dale S. Sawyer, Department of Earth Science, Rice University, MS 126, P.O. Box 1892, Houston, Texas 772511892, U.S.A., e-mail: dale@rice.edu.

Millard F. Coffin, Ocean Research Institute, University of Tokyo, 1-15-1 Minamidai, Nakano-ku, Tokyo 164-8639, Japan.

Timothy J. Reston, Subsurface Group, Earth Sciences,
School of Geography, Earth and Environmental Sciences, University of Birmingham, B15 2TT, U.K.

Joann M. Stock, Seismological Laboratory 252-21, California Institute of Technology, 1200 East California Boulevard, Pasadena, Calif. 91125, U.S.A.

John R. Hopper, Department of Geology and Geophysics, Texas A\&M University, College Station, Texas 77843-3115, U.S.A.

\section{Related Web Links}

IODP: www.iodp.org

InterMARGINS: www.intermargins.org

\section{Figure and Photo Credits}

Figure 12. Photo courtesy of M. Storey (Roskilde University Centre, Denmark).

Figure 13. Photo courtesy of G. Manatschal (CGS-EOST, Strasbourg, France). 